\title{
A PRELIMINARY REPORT ON THE PATHOLOGY OF THE PITUITARY GLAND IN CHILDREN WITH MALNUTRITION
}

\author{
BY \\ CARLOS TEJADA and AGNES BURT RUSSFIELD \\ From the Division of Clinical Pathology, Institute of Nutrition of Central America and Panama, Guatemala, C.A., and \\ the Massachusetts General Hospital, Boston, Massachusetts
}

(RECEIVED FOR PUBLICATION MARCH 21, 1957)

There have been a number of reports on the general pathology of malnutrition, especially kwashiorkor, which have included careful studies of the exocrine glands (Davies, 1948; Jelliffe, Bras and Stuart, 1954; Tejada, 1955). However, little is known of the pathology of the endocrine glands in this condition. Clinical studies of malnourished adults show that they may have pigmentation of the skin, lowered metabolic rates, gynecomastia, asthenia and sexual disturbances (Jacobs, 1948; Klatskin, Salter and Humm, 1947; Zubirán and Gómez-Mont, 1953; Zubirán, Gómez-Mont and Laguna, 1955). Furthermore, there may be severe depletion of protein enzymes (Scrimshaw, Béhar, Pérez and Viteri, 1955; Véhelyi, 1948). Because of these facts, some authors have postulated that pituitary hypofunction comparable to 'panhypopituitarism' is characteristic of extreme malnutrition (González Valero, Garcia Reyes and Gómez-Mont, 1950; Paullada, 1955; Zubirán and Gómez-Mont, 1953; Zubirán et al., 1955). Pathological studies of the pituitary itself, however, are rare, and consist of observations on adults suffering from general malnutrition (Paullada, 1955, Zubirán and GómezMont, 1953) or anorexia nervosa (Richardson, 1939; Siebenmann, 1955; Wilson, 1954). The purpose of this paper is to report the pathological anatomy of the pituitary in children with malnutrition.

\section{Material}

Nineteen children dying in the General Hospital of Guatemala were studied. Clinical data are summarized in Table 1. The children were classified in three groups, according to nutritional characteristics as previously described (Jelliffe, 1955; Scrimshaw, Béhar, Arroyave, Viteri and Tejada, 1956).

(1) Kwashiorkor (Nine Cases). This is a syndrome of severe malnutrition, characterized by growth retardation, apathy, anorexia, oedema, pellagroid dermatosis, changes in the character and colour of the hair and muscular wasting. Autret and Behar (1954) have reviewed this syndrome in Central America, where it is named 'Síndrome pluricarencial de la infancia', and shown it to be identical in its major aspects with kwashiorkor as described elsewhere.

(2) Pre-kwashiorkor (Síndrome de Pluricarencia Incipiente) (Four Cases). This is a state of chronic malnutrition which is quickly followed by frank kwashiorkor after an episode of stress such as may result from infectious diarrhoea. The child shows retardation in growth and bone maturation. The hair is dull and brittle. The skin is usually dry and shows fine desquamation. Psychic changes such as moderate anorexia, apathy or irritability are usually present. In some cases there is also mild oedema.

(3) Marasmus (Six Cases). Marasmus is a state of infantile starvation, characterized by marked underweight, with atrophy of both muscles and subcutaneous fat. The face is monkey-like, due to the absence of fat pads in the cheeks. Neither hair and skin changes nor oedema are ordinarily observed.

Kwashiorkor and mild kwashiorkor are due primarily to a lack of protein in the diet; caloric intake may be adequate or somewhat diminished. Marasmus, on the other hand, is due primarily to a grossly inadequate caloric intake. As combinations of these two conditions may exist, a sharp division of cases is difficult to make. In fact, the element of marasmus is so common in the Central American form of the disease that it is often called marasmic kwashiorkor.

\section{Methods}

A complete necropsy was performed. The immediate cause of death for each case is listed in Table 1. Special attention was paid to the endocrine glands. The adrenals, thyroid and pancreas were carefully dissected and weighed immediately on a laboratory balance. These organs and the gonads were sectioned and stained with haematoxylin and eosin.

The pituitary glands were weighed on a torsion balance after fixation in formol-sublimate and serially sectioned in the horizontal plane. A differential count was performed on three sections of each gland stained by 
TABLE 1

CLINICAL DATA ON 19 MALNOURISHED CHILDREN

\begin{tabular}{|c|c|c|c|c|c|c|}
\hline $\begin{array}{l}\text { Necropsy } \\
\text { No. }\end{array}$ & Sex & Age & $\begin{array}{l}\text { Weight } \\
\text { (kg.) }\end{array}$ & $\begin{array}{l}\text { Height } \\
\text { (cm.) }\end{array}$ & $\begin{array}{l}\text { Days in } \\
\text { Hospital }\end{array}$ & Cause of Death \\
\hline $\begin{array}{l}258 \\
249 \\
273\end{array}$ & $\begin{array}{l}\text { Marasmus } \\
\mathbf{M} . \\
\mathbf{M} . \\
\mathbf{M} .\end{array}$ & $\begin{array}{l}13 \mathrm{mth} \text {. } \\
2 \mathrm{yr} \text {. } \\
3 \mathrm{yr} .\end{array}$ & $\begin{array}{l}4 \cdot 99 \\
4 \cdot 99 \\
6 \cdot 98\end{array}$ & $\begin{array}{l}65 \\
65 \\
85\end{array}$ & $\begin{array}{c}2 \\
3 \\
19 \text { hours }\end{array}$ & $\begin{array}{l}\text { Bronchopneumonia } \\
\text { Bronchopneumonia } \\
\text { Bronchopneumonia }\end{array}$ \\
\hline & & & & & & Acute infectious colitis \\
\hline 350 & M. & 4 yr. & 6.08 & 80 & 8 & $\begin{array}{l}\text { Bronchopneumonia } \\
\text { Acute infectious colitis }\end{array}$ \\
\hline 268 & M. & $8 \mathrm{yr}$. & $9 \cdot 02$ & 93 & 3 & $\begin{array}{l}\text { Bronchopneumonia } \\
\text { Acute infectious colitis }\end{array}$ \\
\hline 253 & M. & $1 \mathrm{yr}$. & $5 \cdot 90$ & 67 & 6 & Lobar pneumonia \\
\hline $\begin{array}{l}244 \\
293 \\
295\end{array}$ & \begin{tabular}{|c|} 
Pre-kwashiorkor \\
M. \\
M. \\
M.
\end{tabular} & $\begin{array}{l}16 \mathrm{mth} . \\
18 \mathrm{mth} \text {. } \\
4 \mathrm{yr} \text {. }\end{array}$ & $\begin{array}{l}9 \cdot 07 \\
5 \cdot 31 \\
9 \cdot 07\end{array}$ & $\begin{array}{l}70 \\
68 \\
88\end{array}$ & $\begin{array}{r}1 \\
13 \\
4\end{array}$ & $\begin{array}{l}\text { Bronchopneumonia } \\
\text { Bronchopneumonia } \\
\text { Bronchopneumonia }\end{array}$ \\
\hline 251 & F. & 9 mth. & $6 \cdot 35$ & 55 & 4 & Bronchopneumonia \\
\hline $\begin{array}{l}282 \\
331 \\
325\end{array}$ & $\begin{array}{l}\text { Kwashiorkor } \\
\text { M. } \\
\text { M. } \\
\text { M. }\end{array}$ & $\begin{array}{l}15 \mathrm{mth} \text {. } \\
18 \mathrm{mth} \text {. } \\
3 \mathrm{yr} .\end{array}$ & $\begin{array}{l}5 \cdot 40 \\
6 \cdot 48 \\
7 \cdot 66\end{array}$ & $\begin{array}{l}70 \\
70 \\
84\end{array}$ & $\begin{array}{r}6 \\
16 \\
15\end{array}$ & $\begin{array}{l}\text { Bronchopneumonia } \\
\text { Bronchopneumonia } \\
\text { Bronchopneumonia with abscess } \\
\text { formation }\end{array}$ \\
\hline $\begin{array}{l}298 \\
281 \\
307 \\
322 \\
278 \\
292\end{array}$ & $\begin{array}{l}\text { M. } \\
\text { F. } \\
\text { F. } \\
\text { F. } \\
\text { F. }\end{array}$ & $\begin{array}{l}5 \mathrm{yr} \\
15 \mathrm{mth} \\
2 \mathrm{yr} \\
3 \frac{1}{2} \mathrm{yr} \\
4 \mathrm{yr} \\
5 \mathrm{yr} .\end{array}$ & $\begin{array}{r}8 \cdot 89 \\
6 \cdot 71 \\
6 \cdot 12 \\
5 \cdot 90 \\
6 \cdot 71 \\
12 \cdot 70\end{array}$ & $\begin{array}{l}90 \\
74 \\
70 \\
77 \\
74 \\
85\end{array}$ & $\begin{array}{r}12 \\
12 \\
2 \\
4 \\
4 \\
2\end{array}$ & $\begin{array}{l}\text { Bronchopneumonia } \\
\text { Bronchopneumonia } \\
\text { Bronchopneumonia } \\
\text { Pyelonephritis } \\
\text { Unknown } \\
\text { Bronchopneumonia }\end{array}$ \\
\hline
\end{tabular}

periodic-acid-Schiff-orange $G$, one through the centre of the gland, one some distance above, and one below the first cut. All the cells in every third oil-immersion field were examined.

The following cell types were classified:

(1) Normal Basophils. These were round or ovoid, intensely Schiff positive, densely granular cells which occur chiefly around the periphery of the anterior lobe in a normal hypophysis.

(2) Amphophils. Amphophils are round or polygonal cells which are frequently larger than the normal basophils and tend to have indistinct cell boundaries. They contain sparser and more weakly Schiff-positive granules, which are often irregularly distributed and may vary in size.

(3) Hypertrophic Amphophils. These cells are characterized by giant nuclei which may be of irregular shape and frequently contain a prominent nucleolus. They are derived from the sparsely granulated Schiff-positive cells through enlargement of the nucleus and degranulation of the cytoplasm.

(4) Acidophils. These are rounded, densely granular cells which are most abundant in the postero-lateral portions of the anterior lobe. The granules are Schiffnegative but stain with orange $G$.

(5) Chromophobes. These are apparently agranular cells which are usually much smaller than the cell types previously described. They are differentiated from the agranular hypertrophic amphophils by the size of the nucleus.

\section{Results}

The findings in the pituitary gland are shown in Table 2. The pituitary weight averaged $108 \mathrm{mg}$. in the children with marasmus, $138 \mathrm{mg}$. in prekwashiorkor and $154 \mathrm{mg}$. in frank kwashiorkor. It ranged from $60 \mathrm{mg}$. in a 13-month-old boy with marasmus to $210 \mathrm{mg}$. in a 45 -month-old girl with kwashiorkor. No gross abnormality was found in any patient.

Normal basophils averaged approximately $8 \%$ in children with marasmus or pre-kwashiorkor, $11 \%$ in those with kwashiorkor. They ranged from 3.7 to $16.8 \%$ of the total differential count. Acidophils averaged approximately $14 \%$ in children with marasmus or kwashiorkor, $16 \%$ in those with pre-kwashiorkor. They were extremely variable, ranging from $1 \cdot 7 \%$ to $33.8 \%$ of the total count. Chromophobes comprised the bulk of the cell population, averaging from 65 to $70 \%$ of the count.

The sparsely granulated amphophils, which previous studies have suggested may be the functionally active cells in the hypophysis (Russfield, 1957), were present in all cases, averaging about $8 \%$ in children with marasmus or kwashiorkor, and $5 \%$ in children with pre-kwashiorkor. They tended to be most numerous in children with very low percentages of well-granulated acidophils. In one gland from a patient with kwashiorkor (Case No. 325) in which only $1.7 \%$ acidophils were found, the amphophils were sufficiently numerous as to suggest adenomatous hyperplasia, and mitotic figures were present. The 
TABLE 2

DIFFERENTIAL COUNTS ON PITUITARIES OF MALNOURISHED CHILDREN

\begin{tabular}{|c|c|c|c|c|c|c|c|}
\hline $\begin{array}{c}\text { Necropsy } \\
\text { No. }\end{array}$ & $\begin{array}{c}\text { Pituitary } \\
\text { Weight (mg.) }\end{array}$ & $\begin{array}{c}\text { Total Cells } \\
\text { Counted }\end{array}$ & NB $\%$ & Ac $\%$ & Chr $\%$ & Amp \% & HA $\%$ \\
\hline $\begin{array}{l}258 \\
249 \\
273 \\
350 \\
268 \\
253\end{array}$ & $\begin{array}{r}\text { Marasmus } \\
60 \\
80 \\
160 \\
70 \\
150 \\
125\end{array}$ & $\begin{array}{l}6,123 \\
4,883 \\
7,077 \\
7,145 \\
5,650 \\
4,093\end{array}$ & $\begin{array}{r}3 \cdot 7 \\
5 \cdot 1 \\
11 \cdot 3 \\
14 \cdot 3 \\
9 \cdot 9 \\
4 \cdot 8\end{array}$ & $\begin{array}{r}26 \cdot 0 \\
5 \cdot 2 \\
2 \cdot 4 \\
17 \cdot 8 \\
5 \cdot 5 \\
26 \cdot 2\end{array}$ & $\begin{array}{l}63 \cdot 6 \\
86 \cdot 7 \\
69 \cdot 4 \\
57 \cdot 5 \\
73 \cdot 9 \\
63 \cdot 8\end{array}$ & $\begin{array}{r}5 \cdot 1 \\
2 \cdot 6 \\
14 \cdot 6 \\
9 \cdot 2 \\
9 \cdot 8 \\
3 \cdot 9\end{array}$ & $\begin{array}{l}1 \cdot 6 \\
0 \cdot 4 \\
2 \cdot 3 \\
1 \cdot 2 \\
0 \cdot 9 \\
1 \cdot 3\end{array}$ \\
\hline Average & 108 & & $8 \cdot 2$ & $13 \cdot 9$ & $69 \cdot 1$ & $7 \cdot 5$ & $1 \cdot 3$ \\
\hline $\begin{array}{l}244 \\
293 \\
295 \\
251\end{array}$ & $\begin{array}{c}\text { Pre-kwashiorkor } \\
110 \\
150 \\
180 \\
110\end{array}$ & $\begin{array}{l}4,342 \\
5,560 \\
7,545 \\
5,581\end{array}$ & $\begin{array}{r}12 \cdot 2 \\
8 \cdot 2 \\
8 \cdot 3 \\
4 \cdot 8\end{array}$ & $\begin{array}{l}14 \cdot 6 \\
10 \cdot 1 \\
16 \cdot 8 \\
23 \cdot 4\end{array}$ & $\begin{array}{l}64 \cdot 5 \\
76 \cdot 1 \\
71 \cdot 8 \\
67 \cdot 0\end{array}$ & $\begin{array}{l}7 \cdot 8 \\
5 \cdot 1 \\
2 \cdot 2 \\
4 \cdot 2\end{array}$ & $\begin{array}{l}0.9 \\
0.5 \\
0.9 \\
0.6\end{array}$ \\
\hline Average & 138 & & $8 \cdot 4$ & $16 \cdot 2$ & $69 \cdot 9$ & $4 \cdot 8$ & $0 \cdot 7$ \\
\hline $\begin{array}{l}282 \\
331 \\
325 \\
298 \\
281 \\
307 \\
322 \\
278 \\
292\end{array}$ & $\begin{array}{c}\text { Kwashiorkor } \\
150 \\
80 \\
130 \\
180 \\
100 \\
200 \\
150 \\
210 \\
190\end{array}$ & $\begin{array}{l}5,676 \\
8,484 \\
7,644 \\
7,327 \\
5,951 \\
7,335 \\
5,645 \\
7,560 \\
6,819\end{array}$ & $\begin{array}{r}9 \cdot 3 \\
11 \cdot 8 \\
11 \cdot 1 \\
9 \cdot 1 \\
9 \cdot 5 \\
11 \cdot 2 \\
7 \cdot 8 \\
10 \cdot 6 \\
16 \cdot 8\end{array}$ & $\begin{array}{r}10 \cdot 6 \\
3 \cdot 0 \\
1 \cdot 7 \\
15 \cdot 9 \\
18 \cdot 8 \\
10 \cdot 1 \\
10 \cdot 2 \\
17 \cdot 3 \\
33 \cdot 8\end{array}$ & $\begin{array}{l}68 \cdot 3 \\
72 \cdot 5 \\
68 \cdot 6 \\
63 \cdot 9 \\
64 \cdot 5 \\
74 \cdot 5 \\
70 \cdot 1 \\
64 \cdot 8 \\
40 \cdot 7\end{array}$ & $\begin{array}{c}10 \cdot 3 \\
10 \cdot 8 \\
15 \cdot 6^{*} \\
9 \cdot 9 \\
4 \cdot 4 \\
2 \cdot 3 \\
10 \cdot 8 \\
6 \cdot 1 \\
7 \cdot 5\end{array}$ & $\begin{array}{l}1 \cdot 5 \\
1 \cdot 9 \\
3 \cdot 0 \\
1 \cdot 2 \\
2 \cdot 8 \\
1 \cdot 9 \\
1 \cdot 1 \\
1 \cdot 2 \\
1 \cdot 2\end{array}$ \\
\hline Average & 154 & & $10 \cdot 8$ & $13 \cdot 5$ & $65 \cdot 4$ & $8 \cdot 6$ & $1 \cdot 7$ \\
\hline
\end{tabular}

* Mitotic figures.

$\mathrm{NB}=$ normal basophils; $\mathrm{Ac}=$ acidophils $; \mathrm{Chr}=$ chromophobes; Amp $=$ amphophils; HA =hypertrophic amphophils.

hypertrophic amphophils which are characteristic of every active pituitary (Mellgren, 1945; Russfield, 1957) were also present in all cases, averaging $1.3 \%$ in patients with marasmus, $0.7 \%$ in pre-kwashiorkor and $1.7 \%$ in marasmus. The range was 0.4 to $3 \cdot 0 \%$.

Because of the inherent variability of the material and the few cases available, the small differences observed among the various groups are not felt to be significant.

In all cases, the thyroid contained follicles of varying sizes. Seven glands contained colloid and 12 did not. The epithelium was usually cuboidal, although in two patients it was columnar. The testes showed only minimal signs of maturation, as would be expected in normal children of this age group. In three ovaries, however, developing follicles were present. The adrenals tended to be small. In eight cases the cortex had a linear pattern, the nuclei were pyknotic and abundant lipoid was present in coarse droplets. In 11 cases, the nuclei were large and vesicular, there were varying degrees of lipoid exhaustion, and the linear cortical pattern was obscured, although no frank nodularity was seen. The thymus was so small it was often difficult to find grossly. Microscopically it showed atrophy in all cases. Islets of Langerhans were abundant in all patients and appeared hyperplastic in nine.
Although no exact correlation between the differential counts in the pituitary and the histology of the end organs was apparent on preliminary survey, further studies are being carried out.

\section{Discussion}

Unfortunately, no necropsies on well-nourished Guatemalan children were available for comparison. The average numbers of basophils in the pituitaries described here were within the normal limits reported by Rasmussen (1950) for well-nourished children in the United States. Acidophils were usually, but not always, decreased. By the criteria of Mellgren (1945), who studied the pituitaries of Scandinavian infants, amphophils and hypertrophic amphophils were often significantly increased.

Previously descriptions of the adult human pituitary in malnutrition have varied widely. In patients dying of anorexia nervosa, both abundant normally granulated basophils and acidophils (Siebenmann, 1955) and decreased degranulated acidophils (Richardson, 1939; Wilson, 1954) have been reported. In one adult female with markedly decreased acidophils, there was hyperplasia of sparsely granulated cells staining with orange $G$ (Wilson, 1954). Zubirán and Gómez-Mont (1953) have studied the pituitaries of 101 adults dying with chronic malnutrition. They report 'evidence of 
atrophy' or 'degenerative lesions' in a high proportion of these, but no differential counts were performed. Paullada (1955), on the other hand, found no morphological alterations in the pituitaries of 30 undernourished adults. It is difficult to compare these reports with our findings because of differences in histological techniques and cell classifications used.

In adult pituitaries stained with P.A.S.-orange G, a hyperplasia of amphophils and a variable decrease in well granulated acidophils has been found to be characteristic of primary deficiency of the adrenals, thyroid or gonads, for which reason it has been postulated that the amphophils are the source of the trophic hormones in man (Russfield, 1957). It has also been found that an increase in the number of sparsely granulated Schiff-positive cells ('intermediate mucoid cells' or amphophils) relative to the number of fully granulated Schiff-positive cells ('maximal mucoid cells' or normal basophils) is the characteristic response of the human pituitary to stress (Currie and Symington, 1955).

The presence of unusually abundant amphophils in malnourished children would, therefore, suggest the production of trophic hormones in response to stress, although it is not possible to be sure of this point without biological analysis. The lipoid depletion seen in many of the adrenals and the striking thymic atrophy in all our patients may well be indirect evidence of A.C.T.H. production. To some extent, these findings resemble those of Siebenmann (1955) in anorexia nervosa and of Uehlinger (1955) in malnourished inmates of concentration camps. We would, therefore, agree with those previous workers who feel that there is no primary pituitary deficiency in malnutrition and that there may, indeed, be some evidence for overproduction of adrenocorticotrophic hormones.
Further studies are being carried out to clarify the role of the pituitary in relation to the other target organs.

\section{Summary}

The pituitary glands of 19 Guatemalan children with malnutrition (kwashiorkor, pre-kwashiorkor and marasmus) were studied histopathologically, differential cell counts being performed. Relative percentages of basophils were usually within normal limits established by others. Acidophils were inconstantly decreased. Sparsely granulated amphophilic cells, thought to be the source of trophic hormones, were often unusually abundant. It was concluded that no morphological evidence for panhypopituitarism had been found.

\section{REFERENCES}

Autret, M. and Behar, M. (1954). Síndrome policarencial infantil (Kwashiorkor) and its prevention in Central America (Food and Agriculture Organization of the United Nations), FAO Nutritional Studies, No. 13, Rome.

Currie, A. R. and Symington, T. (1955). In The Human Adrenal Cortex, Ciba Foundation Colloquia on Endocrinology, 8, 396.

Davies, J. N. P. (1948). Lancet, 1, 317.

González Valero, E., García Reyes, J. and Gómez Mont, F. (1950). Rev. Invest. clin. 2, 179.

Jacobs, E. C. (1948). J. clin. Endocr., 8, 227.

Jelliffe, D. B. (1955). Infant Nutrition in the Subtropics and Tropics. WHO Monogr. Ser. No. 29, Geneva.

, Bras, G. and Stuart, K. L. (1954). W. Indian med. J., 3, 43. Klatskin, G., Salter, W. T. and Humm, F. D. (1947). Amer. J. med. Sci., 213, 19.

Mellgren, J. (1945). Acta path. microbiol. scand., Suppl. 60.

Paullada, J. J. (1955). Rev. Invest. clin., 7, 29.

Rasmussen, A. T. (1950). Amer. J. Anat., 86, 75.

Richardson, H. B. (1939). Arch. intern. Med., 63, 1.

Russfield, A. B. (1957). The Endocrine System: The Adenohypophisis. In Analytical Pathology, pp. 293-360, ed. R. C. Mellors, New York.

Scrimshaw, N. S., Behar, M., Pérez, C. and Viteri, F. (1955). Pediatrics, 16, 378.

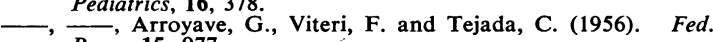
Proc., 15, 977

Siebenmann, R. E. (1955). Schweiz. med. Wschr., 85, 530.

Tejada, C. (1955). Rev. Col. Méd. Guatemala, 6, 1.

Uehlinger, E. (1955). In The Human Adrenal Cortex, Ciba Foundation Colloquia on Endocrinology, 8, 92.

Véghelyi, P. V. (1948). Acta paediat. (Uppsala), 36, 483.

Wilson, R. R. (1954). J. clin. Path., 7, 131.

Zubirán, S. and Gómez-Mont, F. (1953). In Vitam. and Horm., 11, 97. Zubiran, S. and Gomez-Mont, F.(1953). In Vitam. and Horm., 11, 97 